\title{
The Agricultural Water Pollution and Its Minimization Strategies - A Review
}

\author{
Tamirat Wato ${ }^{*} \quad$ Mekides Amare* \\ College of Agriculture and Natural Resource, Department of Plant Science, Bonga University P.O. Box 334, \\ Bonga, Ethiopia
}

\author{
LISTS OF ABBREVIATION AND ACRONYMS \\ BOD - Biological Oxygen Demand \\ BRC - Blackstone River Coalition \\ COD -Chemical Oxygen Demand \\ CWS - Clean Water Services \\ FAO $\quad$-Food and Agriculture Organization of the United Nations \\ IWRM -Integrated Water Resource Management \\ NPSP - Non-point Source Pollution \\ USCC -United States Composting Council \\ US-EPA - The United States, the Environmental Protection Agency \\ WFD -The European Union Water Framework Directives
}

\begin{abstract}
Water is considered the most critical resource for sustainable development in the World. It is essential not just for agriculture, industry and economic process, but it's also the foremost important component of the environment, with a big impact on health and nature conservation. Water pollution in agriculture is recognized worldwide. However, unlike point sources, the experience worldwide is that non-point source (NPS) pollution is difficult to manage effectively due to its inherently diffuse nature. Water pollution is the contamination of water bodies (e.g. lakes, rivers, oceans, groundwater). Water pollution occurs when pollutants are discharged directly or indirectly into water bodies without adequate treatment to get rid of harmful compounds. Two sorts of water subject to pollution are Surface-water - rivers, lakes, oceans (Uses: drinking, recreational (fishing, boating, swimming, irrigation). Groundwater- occurs beneath a water level in soils or rocks; subject to pollution from toxic chemicals (Uses: drinking, irrigation, etc). Groundwater is being polluted mainly by nitrates. In all country's groundwater is an important source of drinking water. In several areas, the groundwater is polluted to an extent that it is no longer fit to be used as drinking water according to present standards. The economic value of changes in water quality is an important component of the economic assessment of policies to reduce pollution from agricultural production. Many Farmers can take many steps to scale back the loadings of agricultural pollutants to water resources. This study found that both structural and management practices are available for managing water and chemical inputs more efficiently or controlling runoff to attenuate irrigation water pollutions. Those practices include efficient irrigation water management, integrated pest management, comprehensive nutrient management planning, animal waste management, conservation agriculture and industrial waste, sewage and stormwater pretreatment.
\end{abstract}

Keywords: - Water, Water pollution, Pollution types, Water quality, and minimization Measures

DOI: $10.7176 / \mathrm{JRDM} / 64-02$

Publication date: April $30^{\text {th }} 2020$

\section{INTRODUCTION}

Agricultural pollution refers to living and non-living bi-products of farming practices that end in contamination or degradation of the environment and surrounding ecosystems, and/or cause injury to humans and their economic interests. The pollution may come from a selection of sources, ranging from beginning pollution (from one discharge point) to more diffuse, landscape-level causes, also mentioned as non-point source pollution. Management practices play a crucial role in the quantity and impact of these pollutants. Management techniques range from animal management and housing to the spread of pesticides and fertilizers in global agricultural practices (FAO, 2013).

The main characteristics of non-point sources are that they reply to hydrological conditions, aren't easily measured or controlled directly, and specialize in land and related management practices. Water Quality Indices ask two or more parameters that indicate the "healthiness" of water. In some cases, indices reflect ecosystem behaviors; in other cases, they indicate conditions of the aquatic environment (e.g. toxicity) (RIZA, 1994). The water quality impacts of cultivating conventional crops as feedstock for first-generation biofuels are the same as from other farm crops. Direct impacts on water quality arising from pollution through runoff from intensive agricultural production employing fertilizers and differing kinds of pesticides (herbicides, insecticides, 
fungicides) and other malpractices in agriculture, like tillage of unsuitable soils (FAO, 2013).

Integrated pest management is a pest control strategy that uses a range of complementary strategies that together, reduce pests, costs and therefore the use of chemical pesticides. In agriculture, this includes herbicides (weeds), insecticides (insects), fungicides (fungi), nematocides (nematodes) and rodenticides (vertebrate poisons). Irrigation in agriculture also has effects; for instance, the runoff of salts results in the salinization of surface waters; the runoff of fertilizers and pesticides results in surface waters with ecological damage and bioaccumulation in edible fish species. The most pollutants in animal waste are chemical oxygen demand (COD), biological oxygen demand (BOD), ammonia nitrogen (NH3-N), total phosphorus (TP), total nitrogen (TN) and metals (USEPA, 2010; FAO, 2013; Abayneh, 2016).

\section{Water pollution}

Water pollution is the contamination of water bodies (e.g. lakes, rivers, oceans, groundwater). Agricultural water pollution affects plants and organisms living in these bodies of water; and, in most cases, the effect is damaging either to individual species and populations, but also to the natural biological communities. Irrigation water pollution occurs when pollutants are discharged directly or indirectly into water bodies without adequate treatment to get rid of harmful compounds (FAO, 2013).

\subsection{Sources of Water Pollution}

The pollution may come from a variety of sources, those are discussed as follow: -

\subsubsection{Point source pollution}

It is defined as discharge into surface waters at a specific location through a pipe, outfall or ditch. Moreover, it is an observable, specific, and confined discharge of pollutants into a surface or underground water body. For example, surface water discharges from feedlots, food processing plants, and agrochemical processing plants, and groundwater pollution from chemical spills (Zazueta and Haman, 2014; Abayneh, 2016).

\subsubsection{Non-point source pollution (NPSP)}

Non-point source pollution, once mentioned as "diffuse" source pollution, arises from a wide group of human activities that the pollutants have no obvious point of entry into receiving watercourses (FAO, 1996). In contrast, beginning pollution represents those activities where wastewater is routed directly into receiving water bodies by, as an example, discharge pipes, where they're going to be simply measured and controlled. Non-point source pollution is far harder to spot, measure and control than point sources. The term "diffuse" source should be avoided as it has a legal connotation in the United States that can now include certain types of point sources (FAO, 2013)

In the USA, the Environmental Protection Agency (US-EPA) has a thorough permitting system for point discharge of pollutants in watercourses. Thus, in that country, non-point sources are defined as any source which is not covered by the legal definition of "point source" as defined in section 502(14) of the United States Clean Water Act (Water Quality Act) of 2007 (NPS, 2017).

The term "point source" means any discernible, confined and discrete conveyance, including but not limited to any pipe, ditch, channel, tunnel, conduit, well, discrete fissure, container, rolling stock, concentrated animal feeding operation, or vessel or other floating craft, from which pollutants are or may be discharged (FAO, 1996; NPS, 2017). This term does not include agricultural stormwater discharges and returns flow from irrigated agriculture (Shanda et al., 2016).

The main features of non-point sources are that they respond to hydrological conditions, are not easily measured or controlled directly (and therefore are difficult to regulate), and focus on land and related management practices (EPA, 2019). Regulator of point sources in those countries having effective control programs is carried out by effluent treatment according to regulations, usually under a system of discharge permits. In comparison, control of nonpoint sources, especially in agriculture, has been through education, promotion of appropriate management practices and modification of land use (BRC, 2015).

\subsection{Classes of Point Source Pollution}

Agriculture is only one of a variety of causes of non-point sources of pollution, however, it is generally regarded as the largest contributor of pollutants of all the categories. 
Figure 1. Hierarchical complexity of agriculturally-related water quality problems (Rickert, 2003).

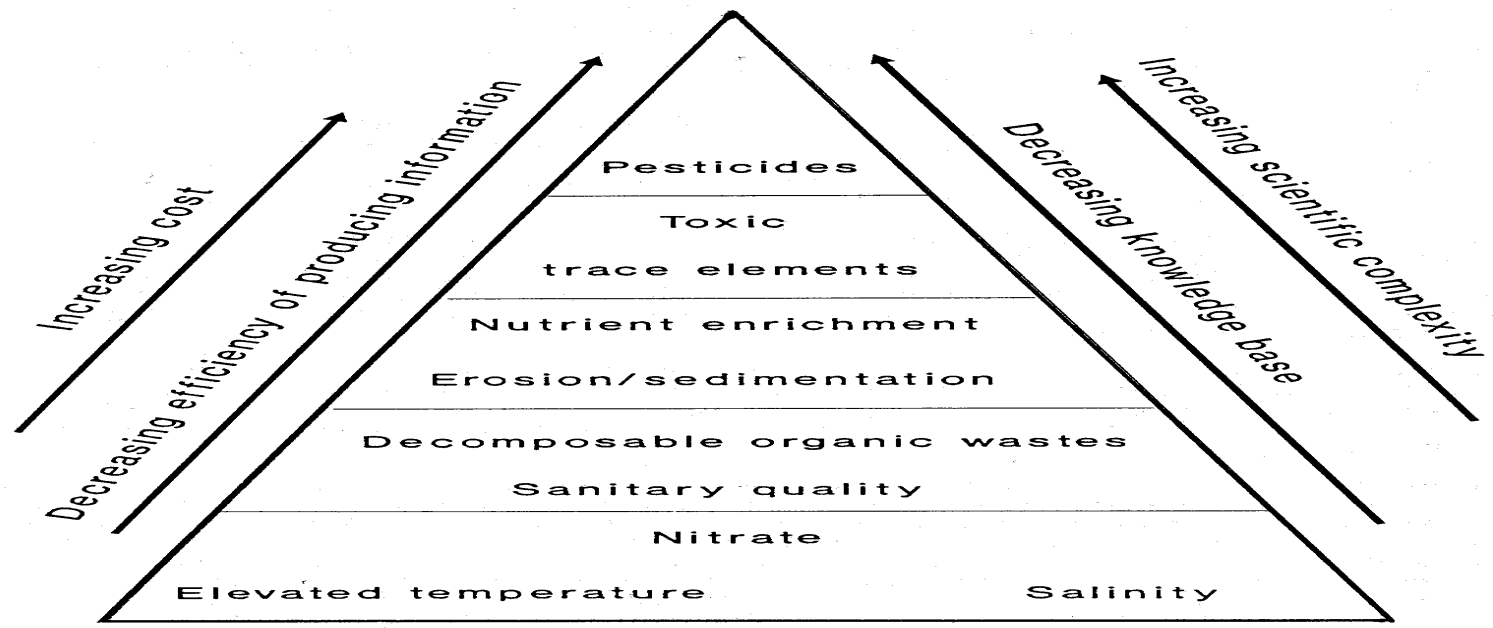

Source: FAO, 1996

Non-point source pollutants, no matter source, are transported overland and through the soil by rainwater and melting snow (FAO, 1996). These pollutants eventually find their way into groundwater, wetlands, rivers, and lakes and, finally, to oceans within the type of sediment and chemical loads carried by rivers (FAO, 1996; Sinha, 2007). According to FAO (1996), as discussed below, the ecological impact of those pollutants ranges from simple nuisance substances to severe ecological impacts involving fish, birds, and mammals, and on human health. The range and relative complexity of agricultural non-point source pollution are illustrated in Figure 1.

Agriculture is additionally cited as the number one description of groundwater pollution within the united states. In 2002, fully forty-nine of fifty states identified that nitrate was the principal groundwater contaminant, followed closely by the pesticide category. The US-EPA (1994) and FAO (1996) concluded that: "more than $75 \%$ of the states reported that agricultural activities posed an enormous threat to groundwater quality."

\subsection{Water quality indices for application to agricultural water quality issues}

Water Quality Indices (WQI) refer to 2 or 3 characteristics that designate the healthiness of the water. In some cases, indices reflect ecosystem behaviors; in other cases, they indicate conditions of the aquatic environment (e.g. toxicity). These indices are commonly planned to regulate the potential for ecosystem dysfunction and to deliver insight into pollution sources and management decisions for source control. Indices tend to be mainly used for descriptive purposes and are not often used straight for water quality management at the field level. The need is for indices that permit rapid assessment of the impact of agricultural runoff and which can be used to make judgments on levels of impacts in space and time as a basis for management decisions concerning the need for controls. There is also the potential to develop indices that link water quality impacts to economic factors relative both to upstream sources and downstream consequences, as a way to evaluate the economic impacts of agricultural runoff (FAO, 2013). Currently, water quality indices are of the following types:

(a) Numerical Indices supported conventional water chemistry: There are commonly six indices that combine various chemical measures of water quality into an integrated index. These commonly include a combination of nutrients, microbiology, dissolved oxygen and, occasionally, metals. Mostly, these are used as expressive tools for measuring river reaches. The more successful indices use a limited number of parameters (e.g. a eutrophication index would use nutrients and dissolved oxygen or BOD) and describe one sort of water pollutant impact (e.g. eutrophication). The most complete recent reference may be a report (in Dutch) produced for RIZA (Netherlands) on chemical indices (RIZA, 1994).

(b) Effects Indicators/Indices: There is a good sort of effects indicators which are often combined into an index. These generally are some measure of a biological reaction to aquatic pollutants. Many of those are used as "screening" tools (as noted above) which may help managers resolve spatially and causally, the character and intensity of the pollutant impact (FAO, 1996).

These indicators include:

I. Bioassay: Usually a scoring system based on the performance of several standardized lab assays using pollutant-sensitive species that are indicative of various trophic levels (e.g. bacteria, algae, invertebrates, vertebrates). Bioassay tends to specialize in toxicity impacts (Keddy et al., 1994).

II. Biotic Indices: There are a variety of standardized biotic indices that are commonly used in Europe for water quality assessment and management. Mostly, these indices are developed from benthic assemblages in rivers and streams. The index represents the nature of the benthic response, mainly to organic pollution (domestic and municipal wastes). These have not been very successful for toxics 
assessment. There are many reviews of biotic indices (Reynoldson and Metcalfe-Smith, 1992).

III. Ecosystem indicators: Increasingly, there is interest in indicators that describe how parts of ecosystems respond to physical and chemical stress. Indicators can include a range of ecological measurements (fish, benthic organisms, habitat, etc.). This technique has proven useful as a means of establishing norms against which managers can measure the success of remediation measures (US-EPA, 1989). This approach has also been used in the United Kingdom, Canada, and Australia (Reynoldson et al. 1995).

IV. Other Effects Indices: There is a wide range of indices that are used to assess nutrient and/or toxic stress. Various of these use fish as a useful replacement for impacts on humans.

These indices include:

$\checkmark \quad$ Measures of fish health using histological (e.g. red/white cell ratio) and pathological measures (size and appearance of organs).

$\checkmark$ Presence/absence of contaminant metabolites in fish bile, liver, etc.

$\checkmark$ Presence of enzymes as part of the detoxification process in organisms (e.g. measures exposure of fish to toxic chemicals).

(c) Other Chemical Indicators: These are integrating (and usually simplifying) chemical measures of groups of compounds. An example is the mapping of chlorine residuals as a measure of total chlorinated material within the water column during a basin. Hot spots within the basin indicate potential problem areas. the target of such indicators is to use simple, inexpensive measures to work out whether problems may exist and to guide decisions on priorities for further (and expensive) qualitative analysis (FAO, 2013).

General Note: Several of those techniques are lower in capital apparatus requirements and advanced in useful information than conventional water chemistry, and are capable of the application by developing countries which typically have a good capacity for biology but much less for advanced environmental chemistry. Such indices do require a shift within the "data paradigm" which remains to be dominated by the (western) chemical approach to water quality assessment.

\subsection{Agricultural inputs and impacts on water quality}

The water quality impacts of cultivating conventional crops as feedstock for first-generation biofuels are the same as from other farm crops. Direct impacts on water quality arising from pollution through runoff from intensive agricultural production employing fertilizers and different types of pesticides (herbicides, insecticides, fungicides) and other malpractices in agriculture, such as tillage of unsuitable soils (FAO, 2013).

\section{A. Pesticides}

Pesticides can have a profound effect on aquatic life and water quality. As pesticide residues are carried to ponds, rivers, and lakes by surface runoff or spray drift they can cause acute poisoning (e.g. fish kills) and also chronic poisoning (e.g. when wildlife is exposed to pesticide levels not immediately lethal). Negative effects on fish that receive repeated sub-lethal doses of pesticides include reduced fish egg production and hatching, lower resistance to disease, decreased body weight, and reduced avoidance of predators (Montesinos E. 2003).

The overall consequences can be lowered population abundance. There are also risks of secondary poisoning when predators consume prey that contains pesticides. This can be of particular concern with persistent chemicals that accumulate and move in food chains. Indirect effects can also occur when habitats or food chains are modified, i.e. when insecticides diminish insect populations fed on by fish and other aquatic animals (EEA,1994).

Pesticides kept in sub-standard conditions pose a threat to both human health and the environment, particularly when kept in urban areas or near water bodies (R Diaz-Chavez et al., 2011). Farmers with insufficient knowledge in pesticide management commonly use older, more toxic, and environmentally persistent chemicals (Ecobichon D. 2001). This may especially be a problem in some developing countries. The absence of stringent regulations, or lack of enforcement of existing regulations, contribute to the problem (Eddleston M, et al., 2002).

\section{B. Fertilizers}

Fertilizers used to increase agricultural yields - mainly nitrogen $(\mathrm{N})$ and phosphorous $(\mathrm{P})$ - may end up in waterways and groundwater. They can have a significant impact on the quality of groundwater and river water, and may also result in eutrophication of wetlands and water bodies (Ongley E, 1996). High nutrient concentrations stimulate algae growth leading to imbalanced aquatic ecosystems, which can experience phytoplankton blooms, production of excess organic matter, and an increase in oxygen consumption leading to oxygen depletion and death benthic organisms that live on or near the seabed.

The Baltic Sea is surrounded by nine countries and five more countries are in the drainage basin but do not border on the sea. Fertilizer runoff from surrounding agriculture lands contributes to a large nutrient load on the Baltic Sea primarily via river discharges which have changed from an oligotrophic clear-water sea into a eutrophic marine environment experiencing summertime algal blooms, where especially the blue-green algae 
that are potentially toxic to humans and animals are a major problem. All sources of pollution to the Baltic Sea were made subject to a convention that was signed in 1974 and entered into force in 1980.

A new convention - Convention on the Protection of the Marine Environment of the Baltic Sea Area - was signed in 1992 by all bordering states and the European Union. This convention entered into force in 2000. Similarly, the excess nitrogen in the Mississippi River has resulted in an anoxic 'dead zone' in the Gulf of Mexico (Bianchi T. et al., 2000). The Black Sea, which is an inland sea, is a third example where large phytoplankton blooms have been observed annually. During the last decades, increased nutrient loads from human sources together with pollution and over-harvesting of fisheries have resulted in a sharp decline in water quality in the Black Sea (Finni T, et al., 2001).

\section{Sediments}

Pollution by sediments is also associated with agriculture practices as they can develop erosion and sedimentation which may produce physical (e.g. turbidity in water) and chemical impacts (e.g. organic chemicals associated with sediments) (Milliman, J.D et al., 1983).

\section{Manure and sludge}

Manure and sludge from wastewater treatment can be valuable sources of nutrients and contribute to maintaining/ improving the soil carbon content and productivity. But especially when spreading takes place on frozen ground, high nutrient runoff can result in high levels of contamination of receiving waters by pathogens, metals, phosphorus, and nitrogen leading to eutrophication and potential contamination (Ongley E, 1996). Additionally, groundwater can be polluted, specifically by nitrogen.

\section{E. Irrigation}

Irrigation in agriculture also has effects; for example, the runoff of salts leads to the salinization of surface waters; the runoff of fertilizers and pesticides leads to surface waters with ecological damage and bioaccumulation in edible fish species (FAO, 2013).

\section{F. Tillage and plowing}

Tillage and plowing in unsuitable soils can promote sediment/turbidity (sediments carry phosphorus and pesticides adsorbed to sediment particles) and siltation of river beds and loss of habitat, spawning ground (Ongley E, 1996). Tillage and plowing should also be considered when removing agricultural residues for the lingo-cellulosic process, as it encourages erosion.

\subsection{Forestry inputs and impacts on water quality}

Besides impacts associated with the cultivation, other practices associated with biomass production for energy, such as harvest residue extraction and the growing of trees without undergrowth, can lead to negative impacts, including soil erosion causing sedimentation of water bodies and reduced ability of precipitation to penetrate the soil and replenish groundwater supplies (Jørgensen et al., 2000). Increased demand for lingo-cellulosic biomass can change the way bio-energy production affects water quality. Removal of lingo-cellulosic harvest residues can lead to 'negative impacts, but if increased demand for lingo-cellulosic biomass leads to shifting in land use toward a larger share of perennial herbaceous plants and woody plants (e.g. willow, poplar, eucalyptus) that are grown in multiyear rotations, positive effects for water quality can be expected. Such plants are generally considered as more beneficial for the water quality in a certain area due to their less-intensive management practices, for example, employing weed control only during the establishment phase, tillage only before the establishment phase, and lower inorganic fertilization than conventional food/ feed crops (FAO, 2013).

Based on the observation that replacement of arable crops with perennial grasses and SRC can lead to an improvement of water quality, integration of SRC into the agricultural landscape has been proposed as a strategy to meet EU obligations in terms of water quality expressed in the Water Framework Directive On good land, SRC is likely to increase water quality associated with land used for farming since its minor agro-chemical requirements (Naphtali John and Atiman Kasima Wilson, 2016). There is some evidence that in particular locations, nitrate leaching could be a problem from applications of fertilizers and sewage sludge. However, it has also been suggested that mixtures of trees and grasses used as energy crops could be cultivated along waterways to act as a buffer preventing nutrient runoff from agricultural land (Hall RL, 2003).

The use of SRC as vegetation filters for cleaning nutrient-rich water is further discussed, including the case where SRC is established as buffer strips to capture nutrient-rich runoff water from intensively managed agriculture lands. The production of energy from wood has a life cycle that produces environmental burdens and impacts on the hydrologic system at various stages (Malkki H, et al., 2001). Most concerns have been focused on forest operations such as harvesting, road network, development, site preparation, fertilization, herbicide use, ash recycling, and regeneration site preparation (Ranney JW et al., 1994). These impacts are transitory but generally well-dispersed throughout watersheds. They can also affect the hydrological process and pollute water directly or indirectly through the use of fertilizers, pesticides, and sediments among others. 
These impacts include: -

\section{A. Hydrologic processes}

The hydrological process can be affected, for instance, by harvesting. The hydrologic cycle quantifies the interactions between the atmosphere, geo-sphere, biosphere, and hydrosphere. Since water is a primary driving force in ecosystem processes and fluxes, water quality reflects the net effects of these processes and disturbances that occur on watersheds (Hewlett JD, 1982). The percentage distribution of water movement changes somewhat in an arid shrub, grassland, and woodland ecosystems, and can vary considerably in watersheds disturbed by climate change, harvesting, burning, insect defoliation, windthrow, land use conversions, mining, and agriculture precipitation inputs consist of rain, snow, and sleet (100\%). Fluxes, or movement pathways for water within watersheds, consist of interception, evaporation, transpiration; stem flow, through fall, infiltration, surface runoff, interflow, base flow, and storm flow. They convey variable amounts of dissolved or suspended solids that constitute the physical component of water quality (Swank WT, 1988).

\section{B. Erosion and peak flow}

When a watershed is in good condition, rainfall infiltrates into the soil, and base flows are sustained between storms. Well-vegetated watersheds in good condition generally do not produce damaging peak flows (flashfoods watershed condition is a term that describes the ability of a watershed system to receive, route, store, and transport precipitation without ecosystem degradation (Brooks et al., 2007).

However, in some regions of the world, these destructive stream flows are common, irrespective of watershed condition. Nevertheless, severe fires, poor harvesting practices, over-grazing, conversion to agriculture and urban uses, and other disturbances may alter the watershed condition, reducing it to a moderate or poor level (Gheewala and Jewitt, 2011). With the poor watershed condition, the percentage of infiltrated rainfall is reduced significantly and may produce erosion. Disturbances that destroy, remove, redistribute, or increase plant litter and vegetation, and change soil physical properties, alter the infiltration and percolation capacity of the soil. When watershed conditions deteriorate, the result is increased flood flows and erosion as watershed condition goes from good to poor. Additionally, according to Neary (2002), the loss of organic material by severe burning, harvesting, respiration, oxidation, site preparation, or other disturbances could result in adverse changes in hydrologic conditions in some instances.

\section{Chemical pollution}

Several research studies have examined the effects of forest harvesting on water quality (USDA, 1983). The water quality parameters typically examined by these studies are nitrate-nitrogen $\left(\mathrm{NO}_{3}-\mathrm{N}\right)$, ammonia nitrogen $\left(\mathrm{NH}_{3}-\mathrm{N}\right)$, total $\mathrm{N}$, total phosphorus $(\mathrm{P})$ and orthophosphate $\left(\mathrm{PO}_{4}-\mathrm{P}\right)$, Cations such as sodium $(\mathrm{Na})$, potassium $(\mathrm{K})$, calcium $(\mathrm{Ca})$, and magnesium $(\mathrm{Mg})$, micronutrients, sediment, and temperature. These parameters are of concern for streams being used as water supplies, and for their potential impact on aquatic biota, particularly threatened and endangered species. Changes in water quality parameters discussed here are mostly from studies where entire watersheds were treated uniformly. They rarely examined situations where forest harvesting was done within the confines of much larger catchments where most of the area was not treated at the same time (Neary et al., 1994).

\section{Nutrients}

Nitrate-nitrogen is often used as an indicator of watershed health and water quality. It is a good integrator and indicator of disturbance, and also a critical water quality parameter for human health (Bianchi et al., 2000). For the most part, large increases in $\mathrm{NO}_{3}-\mathrm{N}$ levels in streams draining harvested watersheds have not been observed. The largest increases in $\mathrm{NO}_{3}-\mathrm{N}$ reported in the literature were measured where herbicides were specifically applied to suppress vegetation re-growth and also to nitrogenous fertilizers during forest regeneration, or where nitrogen saturation of ecosystems has reached a critical level due to atmospheric deposition. Severe fire can also cause similar nutrient release (DeBano et al., 1998; Abayneh, 2016).

\section{E. Fertilizers and wood ash}

Compared to agricultural lands, even managed forests have much higher water quality. Certainly, fertilizer use in the forest bio-energy lifecycle is not expected to cause water quality problems, especially when best management practices (BMPs) are used (Aust et al., 2004). Inter-rotation forest fertilization programs can be a source of additional nutrient inputs into streams, but mitigation practices can limit those inputs (Neary et al., 1994). The review by Pitman cautioned that the environmental problems associated with wood ash use are less likely to come from its heavy metal content, which can be partly removed at source during the burn, and more likely to be associated with its high calcium content. This may create a rise in soil $\mathrm{pH}$, increasing microbial populations and the potential mobilization of nitrogen. Although the rise in $\mathrm{pH}$ is potentially beneficial to tree growth on acidic or nutrient-poor soils, it can be accompanied by changes to the ecology and functioning of forest ecosystems (FAO, 2013).

\section{F. Pesticides}

Herbicides and insecticides are sometimes used in bio-energy plantation establishment to reduce weed competition or deal with insect infestations. Analyses conducted in regional environmental impact statements 
indicate that the low concentrations and short persistence of forestry pesticides in surface and groundwater do not pose a significant risk to water quality, aquatic biota, or human health (Pitman, 2006).

\section{G. Sediment Inputs}

Yields of sediment during and after forest harvesting are highly variable depending on such factors as soils, climate, topography, ground cover, and watershed condition. Although sediment yields increase after harvesting as a result of physical disturbance of soil they are usually transient due to vegetation re-growth. The largest increases documented in the literature have been associated with post-harvest mechanical site preparation, slope instability, road construction, or naturally highly erosive soils (R Diaz-Chavez et al., 2011). The cumulative effects of erosion and sedimentation that occurred centuries ago from agriculture or forestry can present forest managers with many challenges (Terrene Institute, 2003). Sediment is an important water quality parameter since it can harm aquatic organisms and habitats, and render water unacceptable for drinking water supply or recreation purposes. The natural variability of sediment regimes in bio-energy forests must be understood before making judgments on the effects of harvesting. The use of the appropriate BMPs and carefully planned harvesting can result in minimal or no additions to stream sediments (Neary, 1994). BMPs are most effective in minimizing sediment inputs to streams or lakes when they are properly planned and implemented before, during, and after harvesting (Aust et al., 2004).

\section{H. Temperature Effects}

A water quality parameter that affects stream biota in temperate forests is water temperature. Forest vegetation shades stream channels from solar radiation, thereby producing stream temperatures that are cooler and less variable than for unshaded sites (Neary, 2002). Increases in temperature that result from canopy removal or thinning in forest harvesting temporarily affect physical, chemical, and biological processes.

The impact on aquatic biota varies considerably, depending on whether or not individual species are eurythermic and the degree to which stream temperature is controlled by solar heating or stream base flow. Adverse changes in stream temperature can be buffered by using streamside management zones as a BMP. The cumulative effects of stream temperature increases are often moderated, as streamflow from harvested areas merge with those from larger, uncut areas. In some ecosystems, stream temperatures are primarily controlled by the temperature of base flow inputs. Therefore, canopy removal by thinning or whole-tree harvesting has little impact on temperature (Neary et al., 1994).

\section{MINIMIZATION STRATEGIES FOR AGRICULTURAL WATER POLLUTION}

There are both structural and management practices available for managing water and chemical inputs more efficiently and controlling runoff to minimize irrigation water pollutions. Those practices include efficient irrigation water management, integrated pest management, comprehensive nutrient management planning, animal waste management, conservation agriculture, and industrial waste and sewage pretreatments.

\subsection{Industrial waste and sewage pretreatment program}

In addition to wastewater from residential and commercial sources, wastewater treatment facilities also receive wastewater from industrial users. The solid waste treatment and resource recovery technologies that can be applied include aerobic composting, sanitary landfill and incineration (FAO, 2013).

3.1.1. Aerobic composting - is a microbiological process in which organic domestic waste is biodegraded into an organic soil conditioner and fertilizer. The process uses specific conditions of temperature, humidity, carbon and nitrogen ratio and ventilation, together with the application of bacteria, fungi, actinomycete (bacteria) and/or other microorganisms that are widely distributed in nature, to biodegrade organic domestic waste into stable humus (used as fertilizer). The compost product is dark brown and smells of soil; it is an excellent soil conditioner for the soil reaction.

3.1.2. Sanitary landfill - is the burial of domestic waste. This requires specific conditions to prevent the penetration of rainwater, and the bottom of the landfill is sealed to prevent the percolation of liquids from the waste into the groundwater and to prevent contamination of nearby water wells. In modern systems, methane gas emissions from the landfill are captured and used as fuel.

3.1.2.1 Incineration - is widely used internationally to burn waste in high-temperature ovens. This method can be effective if carried out properly; if not it can produce a variety of toxic gases and by-products during the combustion process.

\subsection{The regulatory framework to control irrigation water pollution}

Water pollution in agriculture is recognized worldwide. However, unlike point sources, the experience worldwide is that non-point source (NPS) pollution is difficult to regulate effectively because of its inherently diffuse nature. The European Union Water Framework Directive (WFD) was adopted in 2000 (European Council, 2000; FAO, 2013) as a means of protecting inland surface waters (rivers and lakes), transitional waters (estuaries), coastal waters and groundwater. The WFD uses the integrated water resource management (IWRM) 
approach in which the river basin is the management unit for water. The directive requires the Member States to create management plans for each river basin on a six-year cycle. Point and Non-point source pollution are to be managed using an integrated approach (FAO, 2013).

Many countries in Sub-Saharan African have national policies, strategies (e.g., National Environment Action Plans) and legislation that stipulate the need for appropriate environmental planning and management. These policies usually apply to both public- and private-sector investment in irrigation (McCartney et al., 2007).

\subsection{Integrated Pest Management (IPM)}

The term 'pesticide' includes all chemicals of all types used to kill or control pests. In agriculture, this includes herbicides (weeds), insecticides (insects), fungicides (fungi), nematocides (nematodes) and rodenticides (vertebrate poisons) (FAO, 1996; SDWF, 2016). IPM is a pest control strategy that uses a variety of complementary strategies that together, reduce pests, costs and the use of chemical pesticides. Farmers practicing IPM follow four steps (; FAO, 2013; USEPA, 2017):

A. Set action thresholds: Formerly taking any pest control action, Integrated Pest Managements primarily sets an action threshold, a point at which pest populations or environmental conditions indicate that pest control action must be taken. The detection of a solitary pest does not mean control is desired. The level at which pests will become an economic threat is critical to guide future pest control decisions (Krishna. 2015).

B. Monitor and identify pests: Not all insects, weeds or other living organisms require control. Many organisms are innocuous, some even beneficial. IPM programs work to monitor and accurately identify pests, so appropriate decisions can be made for their control in conjunction with action thresholds. This monitoring and identification ensure that pesticides will be used only when they are needed and that only the right pesticide will be used.

C. Prevention: The first step in an IPM program is to take preventative measures such as rotating between different crops, selecting pest-resistant varieties and planting pest-free rootstock. These control methods can be effective and cost-efficient and present little to no risk to people or the environment.

D. Control: Once monitoring, identification, and action thresholds indicate that pest control is required, and preventive methods are no longer effective or available, IPM programs evaluate the proper control method both for effectiveness and risk (USEPA, 2017). According to there reports, effective, less risky pest controls are chosen first, including highly targeted chemicals, such as pheromones to disrupt pest mating, or mechanical control, such as trapping or weeding. If further monitoring, identification, and action thresholds indicate that less risky controls are not working, then additional pest control methods would be employed, such as targeted spraying of pesticides. The last and the final report in IPM is broadcast spraying of non-specific pesticides.

\subsection{Capturing and Recycling Agricultural Runoff as a Pollution Prevention Strategies}

Capture and recycle technology began as a technique to conserve water and to scale back water and energy costs. A recycling system can also control stormwater. The value of implementing a system depends on various factors like the quantity of runoff to be captured and topographic features that determine the number of retention basins needed to capture runoff. Capture and recycle system feature a network of channels and ditches that capture runoff irrigation water from the nursery beds, and divert it to basins that retain the water. The water can then be pumped from these retention basins back onto production areas or to a storage basin (Wilson and Broembsen, 2006).

Another advantage of recycling may be a modest decrease in fertilizer costs because of the recycling of nutrients within the irrigation water. Also, with the capture and recycle system, there's more management flexibility within the use of various sorts of fertilizers, in scheduling fertilizer applications, and in using certain pesticides in mitigating pest outbreaks. High levels of Phytophthora could warrant the disinfection of recycled water from fast turnover retention basins or sumps. Water also can be filtered before reuse to get rid of most pathogens (Abayneh, 2016). Retention of captured runoff in basins reduces pathogen levels because of natural processes like settling out and biological and physical degra $\neg$ dation (Wilson and Broembsen, 2006; Abayneh, 2016).

\subsection{Conservation Agriculture}

Conservation agriculture uses a variety of techniques to reduce soil erosion during all stages of ploughing, planting, harvesting, and fallowing. It combines minimum or no-till-systems with measures to optimize the protective cover of living vegetation (including cover crops), mulch and resulting litter layer, as well as crop diversification to make better use of the soil profile for moisture and nutrients through alternating species. It is characterized by three linked principles, namely:

a. Minimum mechanical soil disturbance, 
b. Permanent organic soil cover, and

c. Diversification of crop species grown in sequences and/or associations.

Conservation tillage is the minimum (or zero) use of hand or mechanical tillage practices for preparing the land and planting, leaving at least 30 percent residue cover on the ground. Crop residues provide a more effective protective cover over the soil and are more readily broken down into litter and incorporated as soil organic matter by soil organisms.

\subsection{Using Compost to reduce water pollution}

Organic wastes, such as manure, wastewater treatment solids, or even grass clippings, are a major source of nonpoint source pollution. The process of composting takes these raw materials and stabilizes them under controlled conditions. Stabilizing the fabric takes the nutrients, like nitrogen, and ties them up within the compost's organic matter (CDT, 2008; Abayneh, 2016). The nutrients are slowly released over time, increasing the opportunity for uptake by plants and reducing downstream water pollution problems. For that reason, composting is recognized as a Best Management Practice by the EPA's Non-Point program (USEPA, 2003; USCC, 2008) compared to raw manure, not only is composted manure itself less polluting but as a manufactured product it can be transported further from the place of generation (USCC, 2008).

Using compost has several positive benefits. The use of compost improves the water dynamics of soil, including increasing water infiltration, percolation, and water holding capacity (Abayneh, 2016; Davis, 2017). This can reduce irrigation needs, and associated leaching potential. For example, a study within the pollutionprone sandy soils of Florida showed that annual applications of $3 / 4-1$ " of compost per acre would end in increased soil moisture and reduced water seepage below the root zone, "thus reducing the potential for nitrogen and atrazine (an herbicide) to leach into groundwater" (Savabi, 2005; USCC, 2008; Davis 2017).

Figure 2. Sediment removal comparison

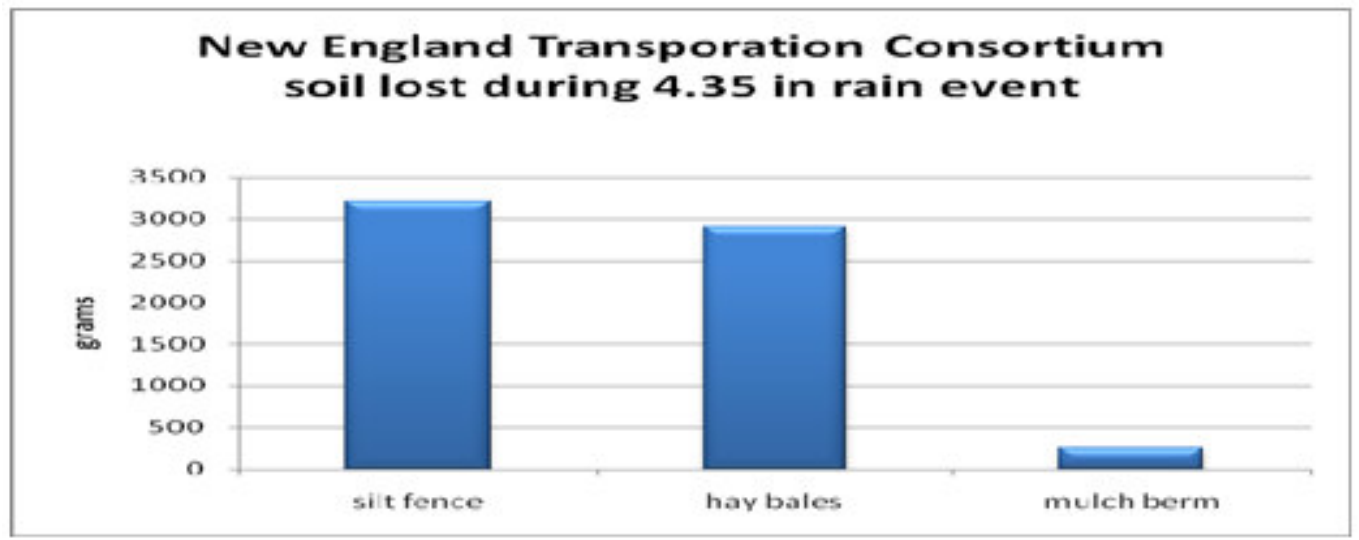

Source: Dumars et al., 2000; USCC, 2008; Abayneh, 2016.

Since it's not always feasible to prevent erosion during construction, compost can be effectively used to filter stormwater leaving a construction site. Typically, construction sites use silt fence or hay bales to supply sediment control around the perimeter of the location. Using composted mulch, either in freestanding filter berms or contained in long tubes called "filter socks", has proved to be far more effective. Although the normal practices act as temporary stormwater detention devices, relying on gravity to settle out solids, the compostbased practices work both as detention and a filter, removing suspended solids, settleable solids, together with soluble pollutants like petroleum hydrocarbons and nutrients (Faucette, 2006; USCC, 2008; Abayneh, 2016).

\subsection{Comprehensive Nutrient Management}

Improved soil, water, and fertilizer management practices are needed to improve the production and environmental performance of irrigated agriculture (Siyal et al., 2012). Sustainable agricultural production and productivity incorporate the thought that natural resources should be accustomed to generate increased output and incomes without depleting the natural resource base. In this context, integrated nutrient management (INM) maintains soils as storehouses of plant nutrients that are essential for vegetative growth. INM's goal is to integrate the utilization of all-natural and man-made sources of plant nutrients, so that crop productivity increases in an efficient and environmentally benign manner, without sacrificing soil productivity of future generations. INM relies on several factors, including appropriate nutrient application and conservation and therefore the transfer of data about INM practices to farmers and researchers (Fairhurst, 2012).

\subsection{Animal Waste Management}

The problem of water quality in the livestock industry is from solid and liquid waste (manure). Liquid manure is 
urine or any manure to which water is added in the collection, storage or treatment processes. The main pollutants in animal waste are chemical oxygen demand (COD), biological oxygen demand (BOD), ammonia nitrogen $\left(\mathrm{NH}_{3}-\mathrm{N}\right)$, total phosphorus $(\mathrm{TP})$, total nitrogen $(\mathrm{TN})$ and metals. Animal wastes often contain growth hormones and antibiotics. The storage, processing, handling and spreading of manure play an important role both in reducing water pollution and increasing economic benefits to farmers, especially as manure adds organic fertilizer and carbon to the soil and promotes good soil texture. Excessive use of manure leads to a situation where the soil and crops cannot fully absorb the nutritive components in manure and lead to surface and groundwater pollution. Therefore, the amount of manure used must be part of a comprehensive fertilizer management plan (FAO, 2013).

Figure 3. Total pollution loads released to the environment from pigs, cattle, and poultry, from 2000 to 2007.

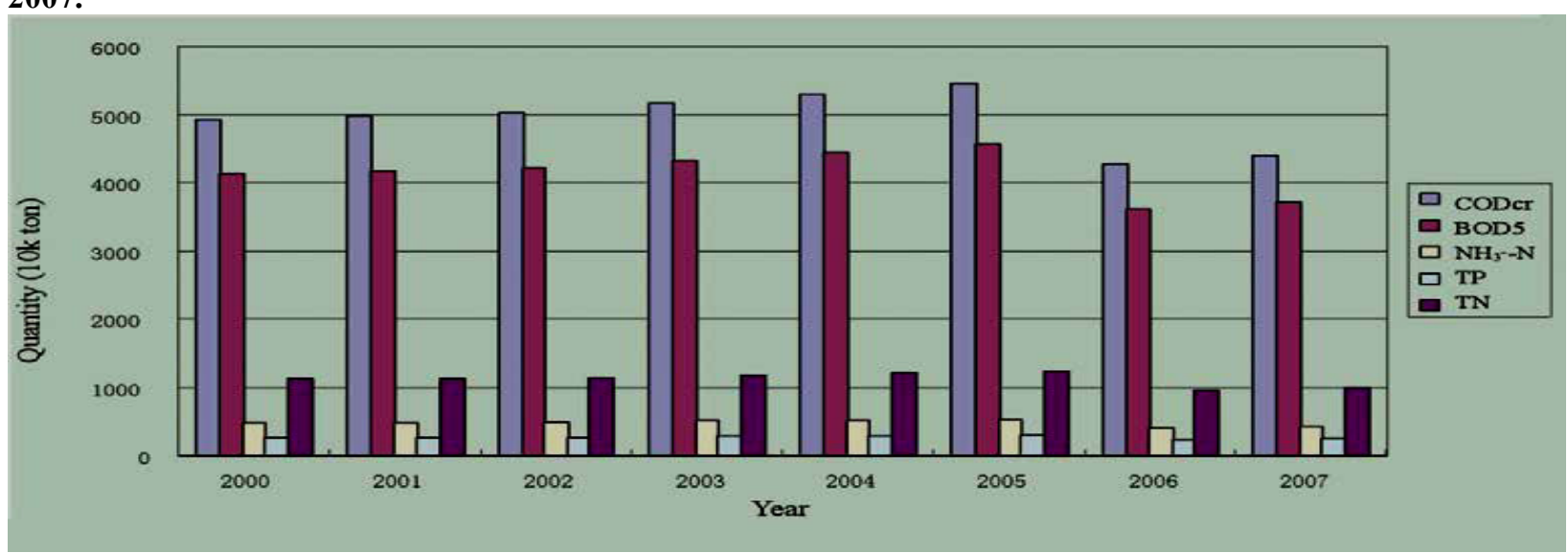

Source: China Animal Husbandry Yearbook, 2008; FAO, 2013; Abayneh, 2016

\subsection{Integrated Drainage and Wetland Management}

This system combines irrigation, drainage, and wetland. The irrigated area is higher than the pond; field drainage is through pipes or ditches to the wetland where nitrogen and phosphorus are biodegraded by wetland plants. Water from the wetland can be reused in the field, or discharged to nearby watercourses. Compared with conventional irrigation and drainage, research shows that total nitrogen $\mathrm{TN}, \mathrm{NH}_{4}{ }^{+}-\mathrm{N}$, and $\mathrm{NO}_{3}-\mathrm{N}$ concentrations at the outlet of the wetland were lowered by 17 percent, 14 percent and 51 percent respectively compared with the field drainage water (Peng et al., 2009; FAO, 2013).

\subsection{Storm-Water Treatment}

It is the removal of pollutants from storm-water before releasing the storm-water to the public storm-water system. Source control is the practice of preventing contact between storm-water and potential sources of pollutants. By providing soil- or landscape-based permanent storm-water treatment, development projects can protect water quality and reduce the maintenance frequency of the treatment facilities. Most soil-based treatment systems are bio-retention areas and bio-swales, a swale lined with grass or other vegetation. Other systems include but are not limited to paver systems, vertical pipes/boxes or dry good boxes with a mixture of soil, sand, and rock, and other systems as new methodologies are developed (ACPWA, 2016).

\section{SUMMARY AND CONCLUSIONS}

Water is considered as the most critical resource for sustainable development in most developing countries. It is essential not just for agriculture, industry and economic process, but also, it's the foremost important component of the environment, with a major impact on health and nature conservation. Chemical pollution of surface water can create health risks because such waterways are often used directly as pure water sources and thus, used for drinking water or connected with shallow wells used for drinking water. Besides, waterways have important roles for washing and cleaning, for fishing and fish farming, and recreation.

Another major source of beverage is groundwater, which regularly has low concentrations of pathogens because the water is filtered during its transit through underground layers of sand, clay, or rocks. However, toxic chemicals like arsenic and fluoride are often dissolved from the soil or rock layers into groundwater. Chemicals can enter waterways from a point source or a nonpoint source. Point-source pollution is due to discharges from one source, like an industrial site. NPS (Non-point-source) pollution contains numerous small sources that combine to cause significant pollution. For example, the movement of rain or irrigation water over land picks up pollutants like fertilizers, herbicides, and insecticides and carries them into rivers, lakes, reservoirs, coastal waters, or groundwater. 
Another nonpoint source is storm-water that collects on roads and eventually reaches rivers or lakes. Water pollution control requires action at all levels of the hierarchical framework. The ideal method to abate diffuse chemical pollution of waterways is to minimize or avoid the use of chemicals for industrial, agricultural, and domestic purposes. Adapting practices like organic farming and integrated pest management could help protect waterways. Chemical contamination of waterways from industrial emissions could be reduced by cleaner production processes. The main pollutants in animal waste are chemical oxygen demand (COD), biological oxygen demand (BOD), ammonia nitrogen (NH3-N), total phosphorus (TP), total nitrogen (TN) and metals.

The economic value of changes in water quality is an important component of the economic assessment of policies to reduce pollution from agricultural production. Other interventions include proper treatment of hazardous waste and recycling of chemical containers and discarded products containing chemicals to reduce solid waste buildup and leaching of toxic chemicals into waterways. A variety of technical solutions are available to filter chemical waste from industrial processes or otherwise render them harmless.

\section{REFERENCES}

Abayneh Wubetu. (2016). Review Paper on Irrigation Water Pollution and Its Minimization Measures. Journal of Biology, Agriculture, and Healthcare: 6(21):72-81.

Alameda Country Public Works Agency (ACPWA). (2016). Storm-water Quality Control Requirements. California.

Aust WM. and Blinn CR. (2004). Forestry best management practices for timber harvesting and site preparation in the eastern United States: an overview of water quality and productivity research during the past 20 years (1982-2002). Water Air Soil Poll 4:5-36 (2004).

Bianchi T, Engelhaupt E, Westman P, Andren T, Rolff C, and Elmgren R. (2000). Cyanobacterial blooms in the Baltic Sea: Natural or human-induced? Limnol Oceanogr 45(3):716-726.

Blackstone River Coalition (BRC). (2015). A Small Farm Owner's Guide to Protecting Water Quality in the Blackstone Valley. The USA.

Brooks KN, Folliott PF, Gregerson HM, and DeBano LF. (2007). Hydrology and the Management of Watersheds. Iowa State University Press, Ames.

Cassandra Davis. (2017). Knox Country Stormwater Managements.

CDT (California Departments of Transportation). (2008). Annotated Bibliography and Literature Review Summary for the Compost Reconnaissance Study. http://www.dot.ca.gov/hq/env/stormwater/index.htm.

Coffs Harbour. (2001). New South Wales, Australia. New Zealand Forest Research Institute, Forest Research Bulletin No. 223.

Daniel G. Neary. (2002). Impacts of Wildfire Severity on Hydraulic Conductivity in Forest, Woodland, and Grassland Soils. Hydraulic Conductivity - Issues, Determination, and Applications.

DeBano LF, Neary DG, and Folliott PF. (1998). Fire's Effects on Ecosystems. John Wiley \& Sons, New York.

Ecobichon D. (2001). Pesticide use in developing countries. Toxicology:160(1-3):27-33.

Eddleston M, Karalliedde L, Buckley N, Fernando R, Hutchinson G, Isbister G et al. (2002). Pesticide poisoning in the developing world - a minimum pesticides list. Lancet 360(9340):1163-1167.

EEA. (1994). European River and Lakes: Assessment of their environmental state. European Environment Agency, Monograph \#1, Copenhagen, Denmark.

Environmental Impact Statement, Vegetation Management in the Piedmont and Coastal

FAO (Food and Agriculture Organization of the United Nations). (1996). Pesticides as water pollutants.

FAO (Food and Agriculture Organization of the United Nations). (1996). Control of water pollution from agriculture. FAO irrigation and drainage paper 55.

Fedro S. Zazueta and Dorota Z. Haman. (2018). Potential Impacts of Improper Irrigation System Design.

Finni T, Kononen K, Olsonen R, and Wallström R. (2001). The history of cyanobacterial blooms in the Baltic Sea. Ambio 30(4):172-178.

Food and Agriculture Organization of the United Nations (FAO). (2013). Guidelines to control water pollution from agriculture in China: Decoupling water pollution from agricultural production. Rome. Italy.

Food and Agriculture Organization of the United Nations (FAO/ECE). (1991). Legislation and Measures for the Solving of Environmental Problems Resulting from Agricultural Practices (With Particular Reference to Soil, Air and Water), Their Economic Consequences and Impact on Agrarian Structures and Farm Rationalization. United Nations Economic Commission for Europe (UNECE) and FAO, Agri/Agrarian Structures and Farm Rationalization Report No. 7. United Nations, Geneva.

Hall RL. (2003). Short rotation coppice for energy production hydrological guidelines. URN 03/883, DTI.

Hewlett JD. (1982). Principles of Forest Hydrology. University of Georgia Press, Athens, GA.

Jørgensen U, Mortensen J. (2000). Combined energy crop production and groundwater protection. In: Do energy crops have a future in Denmark? (Jørgensen, U. ed.). DJF rapport Markbrug no. 29: 97-104.

Keddy, C, Greene, J.C. and Bonnell, M.A. (1994). A Review of Whole Organism Bioassays for Assessing the 
Quality of Soil, Freshwater Sediment, and Freshwater in Canada. Scientific Series No. 198. Ecosystem Conservation Directorate, Environment Canada, Ottawa.

M. P. McCartney, E. Boelee, O. Cofie, and C. M. Mutero. (2007). Minimizing the Negative Environmental and Health Impacts of Agricultural Water Resources Development in Sub-Saharan Africa. International Water Management Institute. Working Paper 117.

Malkki H, Haju T, and Virtanen Y. (2000). Life cycle assessment of logging residue-based energy, in Bioenergy from Sustainable Forestry: Principles and Practice, Proceedings of IEA Bioenergy task 18 Workshop, ed by Richardson J, Bjorhaden R, Hakkila P, Lowe AT and Smith CT (compilers). Milliman, J.D. and Meade, R.H. 1983. Worldwide delivery of river sediment to the oceans, J. Geol. 91: 1-21. October 16-20.

Mary Bianchi and Thomas Harter. (2002). Non-point Sources of Pollution in Irrigated Agriculture. The University of California.

Montesinos E. (2003). Development, registration, and commercialization of microbial pesticides for plant protection. International Microbiology 6(4): 245-252.

Naphtali John and Atiman Kasima Wilson. (2016). Household Wood Fuel Consumption and Effect on Climate Change in Taraba State, Nigeria. Bassey Andah Journal: V (9), 1-13

Neary DG, Smethurst PJ, Baillie B, Petrone KC, Cotching W, and Baillie CC. (2010). Does tree harvesting in riparian areas adversely affect stream turbidity- preliminary observations from an Australian case study. Journal of Soils and Sediments 10:652-670.

Neary DG. (2002). Environmental sustainability of forest energy production, 6.3 Hydrologic values, in Bioenergy from Sustainable Forestry: Guiding Principles and Practices, ed by Richardson J, Smith T and Hakkila P. Elsevier, Amsterdam.

NPS. 2017. Polluted Runoff: Nonpoint Source Pollution.

Ongley, E.D. (1994). Global water pollution: challenges and opportunities. Proceedings: Integrated Measures to Overcome Barriers to Minimizing Harmful Fluxes from Land to Water. Publication No. 3, Stockholm Water Symposium, 10-14, Stockholm, Sweden. pp. 23-30.

Pitman RM. (2006). Wood ash use in forestry - a review of the environmental impacts. Forestry 79:563-588. Plain. USDA Forest Service, Southern Region Management Bulletin R8-MB-23, pp1248

Ranney JW. and Mann LK. (1994). Environmental considerations in energy crop production. Biomass Bioenerg $6: 211-228$

Reynoldson, T.B., and Metcalfe-Smith, J.L. (1992). An overview of the assessment of aquatic ecosystem health using benthic invertebrates. J. Aquatic Ecosystem Health: 1: 295-308.

Reynoldson, T.B., Bailey, R.C., Day, K.E. and Norris, R.H. (1995). Biological guidelines for freshwater sediment based on Benthic Assessment of Sediment (the BEAST) using a multivariate approach for predicting biological state. Australian Jour. Ecol. (in press).

Rickert D. (1993). Water quality assessment to determine the nature and extent of water pollution by agriculture and related activities. In: Prevention of Water Pollution by Agriculture and Related Activities. Proceedings of the FAO Expert Consultation, Santiago, Chile, 20-23. Water Report 1. FAO, Rome. pp. 171-194.

RIZA, (1994). Chemische water quality indices. Institute for Inland Water Management and Waste Water Treatment (RIZA), Ministry of Transport, Public Works and Water Management.

Rocio Diaz-Chavez, Göran Berndes, Daniel Neary, André Elia Neto, Mamadou Fall. (2011). Review of Water quality assessment of bioenergy production. Society of Chemical Industry and John Wiley \& Sons, Ltd | Biofuels, Bioprod. Bioref. 5:445-463 (2011); DOI: 10.1002/319

S. Gheewala and G. Jewitt. (2011). The Bioenergy and Water Nexus.

SDWF (Safe Drinking Water Foundations). (2016). Pesticides and Water Pollution.

Sh. Krishna. (2015). Devitar VDC- IPM farm visit. Integrated Pest Management (IPM Farming).

Shanda K. Wilson and Sharon von Broembsen. (2006). Capturing and Recycling Irrigation Runoff as a Pollution Prevention Measure. Water Quality Series. Oklahoma State University (OSU).

Swank WT. (1988). Stream chemistry responses to disturbance. In Forest Hydrology and Ecology at Coweeta, ed by Swank WT and Crossley DA, Springer-Verlag, New York.

Terrene Institute. (1993). Proceedings of a Technical Workshop on Sediments. Terrene Institute, Washington.

The United States Composting Council (USCC). (2008). Using Compost Can Reduce Water Pollution www.compostingcouncil.org.

The United States Environmental Protection Agency (US-EPA). (1992). National Pesticide Survey: Update and summary of Phase II results. Office of Water \& Office of Pesticides and Toxic Substances, United States Environmental Protection Agency Report \# EPA570/9-91-021, Washington DC.

The United States Environmental Protection Agency (US-EPA). (1994). National Water Quality Inventory. Report to Congress. EPA-841-R-94 001. Office of Water, Washington, DC.

Thomas Fairhurst. (2012). Africa Soil Health Consortium: Handbook for Integrated Soil Fertility Management. CAB International. 
U.P. Sinha. (2007). Economics of Social Sectors and Environment.

UN - Water. (2015). Wastewater Management- A UN-Water Analytical Brief.

United States Composting Council (USCC). (2008). Using compost can reduce water pollution.

United States Department of Agriculture's (USDA). (2013). California Your farm and Agricultural Water Quality. Natural Resources Conservation Service (NRCS).

USDA. (1983). National Engineering Handbook: Sedimentation. United States Department of Agriculture (USDA), Soil Conservation Service, $2^{\text {nd }}$ Edition.

USEPA (United States of Environmental Protection Agency). (2017). Integrated Pest Management (IPM) Principles. 